\title{
19- Uzaktan öğretim süreçlerinde kullanılan Türkçe dersi materyallerine yönelik öğretmen ve öğrenci görüsslerinin değerlendirilmesi
}

Mehmet FIDAN1

\section{Erdem SARIASLAN2}

\begin{abstract}
Ahmet YILMAZ3
APA: Fidan, M. \& Sarıaslan, E. \& Yılmaz, A. (2022). Uzaktan öğretim süreçlerinde kullanılan Türkçe dersi materyallerine yönelik öğretmen ve öğrenci görüşlerinin değerlendirilmesi. RumeliDE Dil ve Edebiyat Araştırmaları Dergisi, (26), 350-368. DOI: 10.2900o/rumelide.1075617.
\end{abstract}

\section{$\ddot{O} \mathbf{z}$}

Uzaktan öğretim süreçlerinin hedefler, temel alınan müfredat, kazanımlar gibi birçok etken açısından yüz yüze eğitimle eş değer özellikleri bulunmaktadır. Bu özelliklere ek olarak uzaktan ve yüz yüze eğitim süreçleri ders işleniş sırasında kullanılan yöntemler, materyaller, ölçme ve değerlendirme araçları gibi yönlerden farklılaşabilmektedir. Bu durum yürütülen öğretim sürecine uygun yöntem, teknik, materyal, ölçme-değerlendirme aracı vb. geliştirilmesini gerektirmektedir. Suralanan ögelerden materyal, özellikle öğrencilerin derse ilgisini çekmede ve öğretim sürecinin etkililiğini artırmada önemli konumda bulunmaktadır. Bu nedenle kullanılan öğretim metoduna uygun materyal tasarımı ve bu materyallerin kullanılması, kazanımlara ulaşma açısından önemlidir. Bu doğrultuda araştırma sürecinde, uzaktan öğretim süreçlerinde kullanılan Türkçe dersi materyallerine yönelik Türkçe öğretmenlerinin ve öğrencilerin görüşlerinin değerlendirilmesi amaçlanmıştır. Araştırma sürecinde nitel araştırma yöntemlerinden yararlanılmıştır. Türkçe öğretmenlerinin ve öğrencilerin uzaktan öğretim süreçlerinde kullanılan materyallere yönelik görüşlerinin alınması aşamasında standartlaştırılmış açı uçlu görüşme formları kullanılmıştır. Araştırmanın katılımcılarının belirlenmesi aşamasında amaçlı örnekleme yöntemlerinden tipik durum örneklemesinden yararlanılmıştır. Bu doğrultuda araştırmaya toplamda 20 Türkçe öğretmeni ve 90 ortaokul öğrencisi katılmıştır. Araştırmada görüşme formları vasıtasıyla elde edilen verilerin değerlendirilmesinde içerik analizi tekniğinden yararlanılmıştır. Elde edilen verilerin analizi aşamasında her görüşme sorusu doğrultusunda bir başlık (tema) oluşturularak değerlendirme yapılmıştır. Araştırma sonuçları Türkçe öğretmenlerinin görüşleri doğrultusunda değerlendirildiğinde uzaktan öğretim süreçlerinde en çok kullanılan materyaller Türkçe ders kitabı, EBA platformu ve yardımcı kaynaklardır. Araştırmaya katılan öğrencilerin cevapları değerlendirildiğinde ise materyal olarak web araçlarının, Türkçe ders kitabının ve EBA platformunun ön plana çıktığı tespit edilmiştir.

Anahtar kelimeler: Uzaktan öğretim, Türkçe dersi, materyal tasarımı

Doc. Dr., Aksaray Üniversitesi, Eğitim Fakültesi, Türkce ve Sosyal Bilimler Eğitimi (Aksaray, Türkiye), fidanm3838@gmail.com, ORCID, ORCID ID: 0000-0002-9347-2992 [Araştırma makalesi, Makale kayıt tarihi: 25.01.2022-kabul tarihi: 20.02.2022; DOI: 10.29000/rumelide.1075617]

$2 \quad$ MEB, Kayseri İl Milli Eğitim Müdürlüğ̈̈ (Kayseri, Türkiye), erdmsariaslan@hotmail.com, ORCID ID: oooo-0oo2-74350324

MEB, Kayseri İl Milli Eğitim Müdürlüğü (Kayseri, Türkiye), ahmet.yilmaz2538@gmail.com, ORCID ID: oooo-ooo24203-3367

RumeliDE Dil ve Edebiyat Araşttrmaları Dergisi Osmanağa Mahallesi, Mürver Çiçeği Sokak, No:14/8 Kadıköy - İSTANBUL / TÜRKIYE 34714 e-posta: editor@rumelide.com tel: $+905057958124,+902167730616$
Address

RumeliDE Journal of Language and Literature Studies

Osmanağa Mahallesi, Mürver Çiçeği Sokak, No:14/8

Kadıköy - ISTANBUL / TURKEY 34714

e-mail: editor@rumelide.com

phone: +90 $5057958124,+902167730616$ 


\title{
Evaluation of teacher and student views on Turkish lesson materials used in distance education processes
}

\begin{abstract}
Distance education processes have features equivalent to face-to-face education in terms of many factors such as objectives, curriculum and achievements. In addition to these features, distance and face-to-face education processes can differ in aspects such as the methods, materials, measurement and evaluation tools used during the lesson. This situation requires the development of methods, techniques, materials, measurement-evaluation tools etc. suitable for the teaching process. Among the items listed, the material has an important position in attracting students' attention to the lesson and increasing the effectiveness of the teaching process. For this reason, material design suitable for the teaching method used and the use of these materials are important in terms of reaching the gains. In this direction, it was aimed to evaluate the opinions of Turkish teachers and students on developing Turkish lesson materials suitable for distance education processes during the research process. Qualitative research methods were used in the research process. Standardized open-ended interview forms were used to obtain the opinions of Turkish teachers and students about the materials used in distance education processes. Typical case sampling, one of the purposive sampling methods, was used in the determination of the participants of the study. In this direction, a total of 20 Turkish teachers and 90 secondary school students participated in the research. In the study, content analysis technique was used in the evaluation of the data obtained through interview forms. In the analysis phase of the data obtained, an evaluation was made by creating a title (theme) in line with each interview question. When the research results are evaluated in line with the opinions of Turkish teachers, the most used materials in distance education processes are Turkish textbook, EBA platform and additional lesson resource. When the answers of the students participating in the research were evaluated, it was determined that web tools, Turkish textbook and EBA platform came to the fore as materials.
\end{abstract}

Keywords: Distance education, Turkish course, material design

\section{Giriş}

Uzaktan öğretim uygulamalarının son dönemde eğitim-öğretim süreçlerinde sıklıkla kullanılması bu uygulamaların yüz yüze eğitimde olduğu gibi niteliksel ve niceliksel yönlerinin de değerlendirilmesini beraberinde getirmiştir. Nitekim doğal olarak içerik, kazanımlar, uygulayıcı ve katılımcılar açısından uzaktan öğretim süreçleri ile yüz yüze eğitim süreçlerinin eş değer olmasına karşı; her iki öğretim sürecinin özünde barındırdığı bazı niteliklerinin olması beklenilen bir durumdur. Bu nitelikleri genel olarak uzaktan öğretim süreçlerinde kullanılan yöntemler, teknikler, materyaller, ölçme-değerlendirme uygulamaları vb. şeklinde sıralamak mümkündür. Bu açıdan yüz yüze eğitimde olduğu gibi uzaktan öğretim süreçlerinde de uygun yöntem, teknik, materyal, ölçme-değerlendirme uygulamalarının geliştirilmesi/kullanılması gerekmektedir.

Uzaktan eğitime yönelik literatür incelendiğinde araştırmaların öğrenci, öğretmen görüşleri ve eğitim süreçlerinin etkililiğinin değerlendirilmesi doğrultusunda olduğu görülmektedir. Bu doğrultuda araştırmaların sonuçları genel olarak uzaktan öğretim süreçlerindeki çeşitli sorunlar ve olumlu nitelikler alanında gruplanmaktadır. Uzaktan öğretim süreçlerinin öğretmenler tarafından çeşitli boyutlarıyla (verimlilik, tecrübe, teknik imkânlar, ölçme-değerlendirme vb.) eleştirel olarak nitelendirildiği çalışmalara

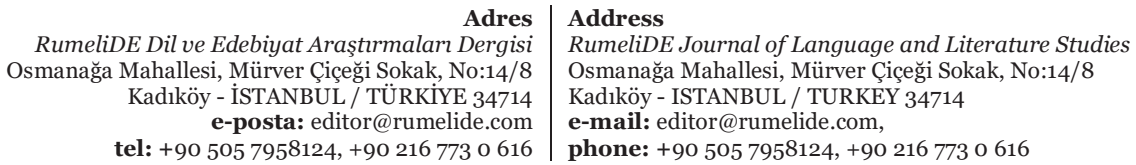


(Karacaoğlu, Karakuş, Esendemir, Ucuzsatar, 2021:140; Kavan, Adıgüzel, 2021:149; Avcı, Akdeniz, 2021: 142-143; Bayburtlu, 2020:149; İskender, 2021:110; Özgül, Ceran, Ylldız, 2020: 408-409; Günaydın, 2021) benzer yönde veli görüşlerinin (Karakuş, Esendemir, Ucuzsatar, Karacaoğlu, 2021:1007) de olduğu görülmektedir. Bu alandaki çalışmasında Günaydın (2021:719) uzaktan öğretim sürecindeki yazma çalışmalarında geri dönüt yönünden sorunlar yaşandığını tespit etmiştir. Konuya üniversite eğitimi açısından yaklaşan Özer ve Çekici (2020:107) araştırmalarına katılan öğretim elemanlarının uzaktan eğitime etkileşim, uygulama açısından eleştirel yaklaştıklarını ifade etmektedir. Eğitmen ve veli görüşlerinin yanı sıra uzaktan öğretim süreçlerinde öğrencilerin durumlarına yönelik çalışmalar da bulunmaktadır (Güngör, Çangal, Demir, 2020; Kuloğlu, 2020). Örneğin, Yabancılara Türkçe öğretimi alanındaki araştırmalarında Güngör, Çangal ve Demir (2020:1183) katılımcı öğrencilerin genelinin uzaktan eğitimden ziyade yüz yüze eğitim almayı istedikleri sonucuna ulaşmıştır.

Uzaktan öğretime yönelik araştırmalar incelendiğinde öğretmenlerin süreç hakkında olumlu görüş bildirdikleri araştırmalar (Doğan, Koçak, 2020) da bulunmaktadır Araştırma sonuçlarında değinilen olumlu niteliklerde genel olarak uygulamaların ve materyallerin etkililiğine vurgu yapıldığ görülmektedir. Özellikle bu uygulamalardan ön plana çıkan EBA'ya (Ĕ̆itim Bilişim Ağı) ve uzaktan öğretim sürecinde daha fazla kullanılmaya başlayan web araçlarına daha çok odaklanılmıştır. Öğretim süreçlerinde materyal kullanımının derse katılım, kazanımları edindirebilme, süreci etkili şekilde yürütebilme gibi birçok duruma etkisi bulunmaktadır. Nitekim bu doğrultuda hem disiplinler/branşlar özelinde hem de sınıf seviyeleri özelinde dersin nitelikleri, kazanımları, öğrencinin seviyesi gibi özellikler göz önünde bulundurularak materyaller geliştirilmektedir. Bu durum uzaktan öğretim süreçlerinde de etkisini göstermektedir. Bu sürece uygun materyal geliştirilmesi, derslerin verimli şekilde yürütülmesi açısından zorunludur. İlgili literatür incelendiğinde uzaktan öğretim süreçlerinde özellikle öğrenci, öğretmen görüssleri vasıtasıyla değerlendirmelerin yapıldı ̆̆ı ve başta EBA olmak üzere süreç ögelerinin çeşitli açılardan araştırıldığı görülmektedir. Örneğin, Aydın (2021:531) öğrencilerin genel nitelikleri açısından EBA uygulamasını olumlu olarak nitelediklerini belirtmiş; Başaran ve Kılınçarslan (2021:194) ise uzaktan öğretim süreçlerinde web 2.0 araçları ile geliştirilen oyunların ilkokul öğrencilerinin temel okuma yazma becerilerinin gelişmesinde etkili olduğunu tespit etmişlerdir. Ancak EBA uygulamasının okuma becerilerine etkisine yönelik öğretmenlerin olumsuz görüşlerini tespit eden araştırma sonuçları (Gürdamar, Şehirli, Toğçuoğlu Ünal, 2020:168-169) da bulunmaktadır.

Yüz yüze eğitim müfredatının uzaktan öğretim süreçlerinde de takip edilmesi, bu müfredat kapsamında oluşturulan ders kitaplarının da uzaktan öğretim ortamında sıklıkla kullanılmasını beraberinde getirmiştir. Bu durum da ders kitaplarının uzaktan öğretim süreçleri açısından değerlendirilmesini sağlamıştır. Türkçe ders kitapları, Türkçe derslerinin yürütülmesinde en temel materyallerden biri olarak ön plana çıkmaktadır. Sarıkaya (2021:259) araştırmasında, uzaktan eğitimin uyguladığı Açı Öğretim Ortaokulu Türkçe ders kitaplarına yönelik çalışmaların yetersizliğini vurgulayarak bu alanda yeni çalışmaların yapılması gerektiğini belirtmektedir. Bu açıdan ders kitaplarının uzaktan öğretime entegre edilmesi sürecinde de bu alana uygunluğun mutlaka göz önünde bulundurulması gerekmektedir. Nitekim son dönemdeki ders kitaplarında bu hususlara (teknolojik gelişmelere) dikkat edildiği görülmektedir. Fidan (2020:2938) araştırmasında Türkçe ders kitaplarında bulunan araştırma yönergelerinde en çok internet kaynaklarına değinildiğini tespit etmiştir. Temel materyallerden biri olan ders kitaplarına ek olarak eğitim öğretim süreçlerinde kullanılacak diğer materyallerin niteliklerine yönelik analizler de bulunmaktadır. Bu konuda Bölükbaş Kaya, Kahraman ve Uysal (2021:80) yabanclara Türkçe öğretiminde uzaktan eğitim süreçlerinde kullanılacak materyallerin bireysel öğrenmeyi destekleyen, etkileşimlilik gibi özelliklerinin olması gerektiğini ifade etmektedir.

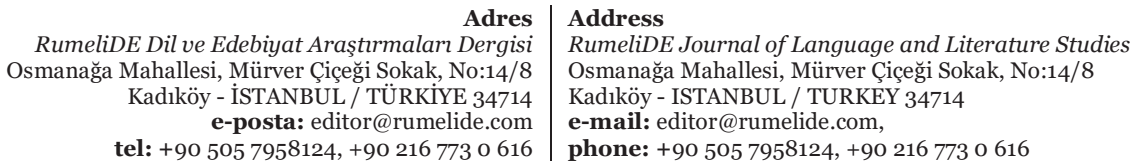


Uzaktan öğretim süreçlerinin kazanım yönünden yüz yüze eğitimle bağlantılı olması, öğretim programlarının bu yönden uygunluğunun sorgulanmasını da beraberinde getirmiştir. Bu yönde çalışmaların mevcut olduğu görülmektedir (Koç, 2021). Öğretim programı kapsamında bir diğer önemli uygunluk alanı ise kullanılan materyallerin, uzaktan öğretim sürecine uygunluğudur. Mete ve Demir (2021:219) araştırmalarına katılan uzmanların, Türkçe Öğretim Programında yer alan bazı kazanımlara dijital içerik geliştirme yönünden eleştirel yaklaştıklarını belirtmektedir. Konu alanına yönelik materyal geliştirme teknikleri kapsamında kuramsal bilgiler de mevcuttur. Örneğin Pilancı, Saltık ve Çalışır Zenci (2020) uzaktan eğitim yoluyla yabancılara Türkçe öğretimi uygulamalarında öğretmenler açısından dikkat edilecek hususları açıklamıştır. Bu kapsamda araştırmada öğretmenlerin ve öğrencilerin uzaktan öğretim süreçlerine yönelik deneyimlerinin analizinin yapılmasının, özellikle materyal geliştirme konusunda katkı sağlayacağı düşünülmektedir.

\section{Yöntem}

Bu araştırmanın temel problemi uzaktan öğretim süreçlerine uygun Türkçe dersi materyallerinin hangi niteliklere sahip olması gerektiğidir. Bu kapsamda araştırmanın temel amacı uzaktan öğretim süreçlerine uygun Türkçe dersi materyallerinin hangi özelliklerinin bulunması gerektiğinin tespit edilmesidir. Bu doğrultuda öğretmenlerin ve öğrencilerin uzaktan öğretim süreçlerinde kullanılan Türkçe dersi materyallerine yönelik yönelik görüşleri alınmıştır. Araştırma sürecinde cevapları aranan sorular şu şekilde sıralanabilir:

1) Uzaktan öğretim süreçlerinde Türkçe derslerinde öğretmenler tarafından hangi materyaller kullanılmıştır?

2) Uzaktan öğretim süreçlerinde Türkçe derslerinde öğretmenler tarafından kullanılan materyallerin öğrencilerin akademik gelişimlerine etkileri nelerdir?

3) Uzaktan öğretim süreçlerinde Türkçe derslerinde öğretmenler tarafından kullanılan materyallerin ders işleyiş süreçlerine etkileri nelerdir?

4) Uzaktan öğretim süreçlerinde Türkçe derslerinde kullanılabilecek materyallerin nitelikleri neler olmalidır?

\subsection{Araştırmanın modeli}

$\mathrm{Bu}$ araştırma sürecinde nitel araştırma yöntemleri kullanılmıştır. Uzaktan öğretim süreçlerinde kullanılan Türkçe dersi materyallerine yönelik öğretmen ve öğrenci görüşlerinin değerlendirilmesinin amaçlandığı bu araştırmada olgubilim çalışmasından yararlanılmıştır. Yıldırım ve Şimşek (2008: 74) bu araştırma türünde verilerin, "araştırmanın odaklandığı olguyu yaşayan ve bu olguyu dışa vurabilecek veya yansitabilecek bireyler ya da gruplar"dan elde edildiğini ifade etmektedirler. Araştırma sürecinde öğretmen ve öğrenci görüşme formları (açı uçlu) vasıtasıyla Türkçe derslerinde uzaktan öğretim sürecinde kullanılan materyallerin etkililiğinin değerlendirilmesi hedeflenmiştir. Ayrıca Türkçe derslerinde uzaktan öğretim süreçlerinde kullanılması uygun olan materyallerinin özelliklerinin neler olduğu konusu da bu kapsamda belirlenmeye çalışlmıştır.

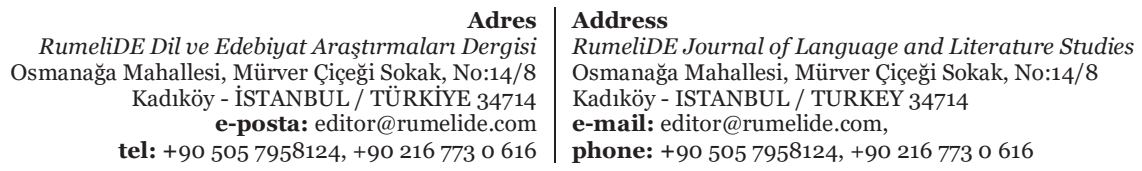




\subsection{Evren - örneklem}

Bu araştırmada amaçlı örnekleme yöntemlerinden tipik durum örneklemesi kullanılmıştır. Bu örnekleme yönteminde genellikle konu hakkında bilgi ve tecrübe sahibi vb. örneklemlere başvurulmaktadır (Yıldırım, Şimşek, 2008:110). Bu vasıta ile uzaktan öğretim süreçlerinde Türkçe derslerinde kullanılan materyallerin, uygulayıcıları olan öğretmenlerin ve katılımcıları olan öğrencilerin görüşleri vasıtasıyla, değerlendirilmesi amaçlanmıştır. Araştırmada gerekli etik ve uygulama izinleri alındıktan sonra görüşmeler yapılmıştır. Bu araştırmanın evreni uzaktan öğretim süreçlerine katılan Türkçe öğretmenleri ve ortaokul öğrencileridir. Araştırmanın örneklemleri ise iki ana grup şeklinde tasarlanmıştır. Örneklem olarak görüşme yapılacak öğretmenlerin seçiminde Kayseri İli Melikgazi ve Kocasinan ilçelerindeki üç farklı okulda bulunan Türkçe öğretmenlerinin görüşlerine başvurulmuştur. Bu doğrultuda birinci okulda yer alan 10 Türkçe öğretmeni, ikinci ve üçüncü okullarda yer alan beşer Türkçe öğretmenin görüşlerine başvurulmuştur. İlgili sayısal verilere Tablo 1'de yer verilmiştir:

Tablo 1. Araştırmaya katılan Türkçe öğretmenleri

\begin{tabular}{lll}
\hline Okul & Frekans & Yüzde \\
\hline 1 & 10 & 50,0 \\
2 & 5 & 25,0 \\
3 & 5 & 25,0 \\
Toplam & 20 & 100,0 \\
\hline
\end{tabular}

Türkçe derslerinde kullanılan uzaktan öğretim uygulamaları materyallerine yönelik değerlendirmelerin öğrenci boyutunun da belirlenebilmesi için aynı okullardaki öğrencilerin görüşlerine de başvurulmuştur. Bu doğrultuda öğrenci seçiminde ana ölçüt uzaktan öğretim sürecinde ortaokulda bulunmak ve Türkçe dersi almak olarak belirlenmiştir. 2020-2021 Ĕ̆itim Öğretim Yılının geneli uzaktan öğretim uygulamaları şeklinde yürütüldüğü için bu süreçte 5,6 . ve 7. sınıfta yer alan öğrenciler araştırmaya katılmıştır. Aranan bu ölçüt kapsamında 2021-2022 Eğitim Öğretim Yılında 6, 7. ve 8. sınıfta yer alan öğrenciler araştırmanın evrenini oluşturmuştur. Araştırmada 5. sınıf öğrencilerinin görüşlerine başvurulmamasının sebebi ise uzaktan öğretim sürecinde bu öğrencilerin ilkokulda bulunmaları ve bu araştırmanın ortaokul Türkçe derslerine yönelik olmasıdır. Araştırmanın değerlendirme sürecinde herhangi bir sınıf değişkeni aranmayacağı için gönüllülük esasına bağlı olarak toplamda 90 öğrencinin görüşleri alınmıştır. Bu öğrencilerden 38’i sekizinci sınıfta, 29’u yedinci sınıfta, 23’ü ise altıncı sınıfta öğrenimlerini sürdürmektedirler. Araştırmaya katılan öğrencilere yönelik sayısal veriler Tablo 2'de yer almaktadır:

Tablo 2. Araştırmaya katılan öğrenciler

\begin{tabular}{cll}
\hline Sinıf & Frekans & Yüzde \\
\hline 6 & 23 & 25,55 \\
7 & 29 & 32,22 \\
8 & 38 & 42,22 \\
Toplam & 90 & 99,99 \\
\hline
\end{tabular}

$\mathrm{Bu}$ kapsamda araştırmaya toplamda 20 Türkçe öğretmeni ve 90 ortaokul öğrencisi katılmıştır. Araştırmaya öğretmenlerin ve öğrencilerin katılımında gönüllülük ilkesi benimsenmiştir. Ayrıca

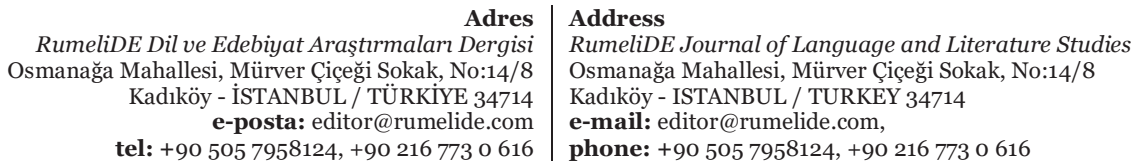


öğrencilerin araştırmaya katılımlarında veli izinli olmalarına dikkat edilmiştir. Katılımcılara istedikleri takdirde araştırma sürecinden ayrılabilecekleri belirtilmiştir.

\subsection{Veri toplama araçları}

Bu araştırmada öğretmen ve öğrencilerin görüşlerinin alınması aşamasında standartlaştırılmış açık uçlu görüşme formları kullanılmıştır. Araştırmada tercih edilen bu yöntemde "görüşmeci etkisi" ve "öznel yargılar" azaltıldığı için elde edilen verilerin analizi daha kolay olmaktadır (Yıldırım, Şimşek, 2008:123). Türkçe derslerinde uzaktan öğretim uygulamaları sürecinde kullanılan materyallere yönelik veri elde edebilmek amacıyla öğretmen görüşme formu ve öğrenci görüşme formu olmak üzere iki farklı görüşme formu kullanılmıştır. Bu doğrultuda araştırma sürecinde kullanılan görüşme formlarının oluşturulmasında ilgili alan yazına ve uzman görüşlerine başvurulmuştur. Oluşturulan araştırma soruları doktora düzeyinde eğitim görmüş ve hâlihazırda Türkçe öğretmenliği yapan üç uzmanın değerlendirilmesine sunulmuştur. Bu yöntem doğrultusunda görüşme formlarında yer alan sorular, uygulayıcılar olan araştırmacıların deneyimlerinden, alan yazından ve uzman görüşlerinden yararlanılarak hazırlanmıştır. Hazırlanan sorularla ilgili uzmanların görüş birliğinde oldukları tespit edilmiştir. Araştırmada kullanılan öğretmen ve öğrenci görüşme formları, elde edilen bilgilerin kıyaslanabilmesi için içerik yönünden benzer nitelikte tasarlanmıştır. Ancak öğrencilerden (genel değerlendirme) farklı olarak öğretmenlere uzaktan öğretim sürecinde kullanılan materyalleri akademik ve ders işleyiş süreçleri açısından değerlendirmelerine yönelik sorular da sorulmuştur. Araştırma sürecinde kullanılan görüşme formlarında yer alan sorular şu şekilde sıralanabilir:

\section{Öğretmen görüşme formunda yer alan sorular}

1) Uzaktan öğretim süreçlerinde Türkçe derslerinde hangi materyalleri kullandınız?

2) Uzaktan öğretim süreçlerinde Türkçe derslerinde kullandığınız materyallerin öğrencilerin akademik gelişimlerine etkilerini değerlendiriniz.

3) Uzaktan öğretim süreçlerinde Türkçe derslerinde kullandığınız materyallerin ders işleyiş süreçlerinize etkilerini değerlendiriniz.

4) Uzaktan öğretim süreçlerinde Türkçe derslerinde kullanılacak materyaller size göre hangi özelliklere sahip olmalıdır?

5) Uzaktan öğretim süreçlerinde Türkçe derslerinde kullanılmasının uygun olduğunu düşündüğünüz/önerdiğiniz materyaller nelerdir? Açıklayınız.

\section{Öğrenci görüşme formunda yer alan sorular}

1) Uzaktan öğretim döneminde Türkçe derslerinde öğretmenleriniz hangi tür materyalleri kullandılar? Açıklayınız.

2) Uzaktan öğretim döneminde Türkçe derslerinde öğretmenlerinizin kullandığı materyalleri değerlendiriniz.

3) Size göre uzaktan öğretimde kullanılacak Türkçe dersi materyallerinin hangi özellikleri olmalıdır? Açılayınız.

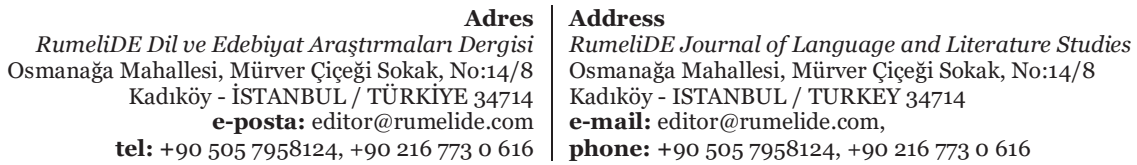


4) Uzaktan öğretimde kullanılacak Türkçe dersi materyallerine yönelik önerileriniz nelerdir? Belirtiniz.

\subsection{Verilerin analizi}

Bu araştırmada, görüşme formları vasıtasıyla elde edilen verilerin değerlendirilmesinde içerik analizi tekniğinden yararlanılmıştır. Görüşme yoluyla elde edilen verilerin derinlemesine analizinde kullanılan bu yöntemle çeşitli kavramlara ve temalara ulaşılmaya çalışılmaktadır (Büyüköztürk, Kılıç Çakmak, Akgün, Karadeniz, Demirel, 2019: 259; Yıldırım, Şimşek, 2008: 227). Bu kapsamda öğretmenlerin ve öğrencilerin görüşleri ayrı başlıklar şeklinde değerlendirilmiştir. Ancak sonuç aşamasında bu iki araştırma grubunun görüşleri, benzerlikleri ve farklıllkları yönünden karşılaştırılmıştır. Araştırmada elde edilen veriler tablolar ve bu tabloların yorumlanması şeklinde sunulmuştur. İlgili tablolar ve açılkamalarda yer alan Ö. kısaltması "Türkçe öğretmenini", Ör. kısaltması ise "öğrenciyi” ifade etmektedir. Ayrıca yorumlamalar sırasında değerlendirmeye yönelik bazı öğrencilerin ve öğretmenlerin görüşlerine de yer verilmiştir.

Araştırmada verilerin analizi aşamasında her görüşme sorusu doğrultusunda bir başlık (tema) oluşturularak değerlendirme yapılmıştır. Araştırma sorularına verilen cevaplar doğrultusunda ilgili başlığa yönelik konu alanları (alt temalar) oluşturulmuştur. Bu aşamada katılımcıların ifadelerindeki anahtar kelimeler vasitasıyla belirtilen görüşün hangi konu alanına dâhil olacağı belirlenmiştir. Araştırmanın son aşamasında ise öğretmen ve öğrenci görüşlerinin karşllaştırılması yapılmıştır. Araştırma sürecinde sınıf düzeyleri yönünden katılımda benzerlik sağlanamadığı için sınıf değişkeni yönünden herhangi bir kıyaslama yapılmayıp bütüncül değerlendirme tercih edilmiştir. Elde edilen veriler vasıtasıyla tümevarımsal yorumlamalar yapılmıştır. Elde edilen verilerin yorumlanması aşamasında görüşme formunda yer alan ifadelerden hareketle formlarda birden fazla konu alanına giren veriler olduğu tespit edilmiştir. Bu yönde ifadelerin bulunduğu formlardaki öğretmenin veya öğrencinin verdiği cevaplar birden fazla konu alanı içerisinde değerlendirilmiştir. Ayrıca bazı katılımcıların cevap vermedikleri sorular da bulunmaktadır. Bu nedenle ilgili bölümler değerlendirmeye alınmamıştır. Bu durum araştırmadaki toplam katılımcı sayısı ile ilgili soruya verilen cevapların frekansı yönünden farklılı oluşmasına neden olabilmektedir.

\section{Etik kurulu izni}

Etik Kurul İzni: Aksaray Üniversitesi İnsan Araştırmaları Etik Kurulunun 20/08/2021 tarih ve 2021/06-23 sayılı etik ilkelere uygunluk kararı ile uygulanmıştır.

Uygulama izni: Kayseri Valiliğinin 27/09/2021 tarih ve 32991881 sayllı oluru ile uygulanmıştır.

\section{Bulgular}

\section{1. Öğretmenlerin Türkçe dersinde uzaktan öğretim süreçlerinde kullanılan materyallere yönelik görüsşleri}

Bu araştırma sürecinde uzaktan öğretim süreçlerinde kullanılan Türkçe dersi materyallerine ve uzaktan öğretim süreçlerinde geliştirilmesi/kullanılması uygun Türkçe dersi materyallerine yönelik öğretmenlerin görüşleri alınmıştır. Araştırma sürecinde kullanılan görüşme formlarında yer alan sorular kapsamında bu veriler yorumlanmış ve başlıklar şeklinde sunulmuştur. Bu doğrultuda öğretmen görüşme formunda yer alan ilk soru "Uzaktan öğretim süreçlerinde Türkçe derslerinde hangi

\footnotetext{
Adres
RumeliDE Dil ve Edebiyat Araşttrmaları Dergisi Osmanağa Mahallesi, Mürver Çiçeği Sokak, No:14/8 Kadıköy - İSTANBUL / TÜRKIYE 34714 e-posta: editor@rumelide.com

Address

RumeliDE Journal of Language and Literature Studies

Osmanağa Mahallesi, Mürver Çiçeği Sokak, No:14/8

Kadıköy - ISTANBUL / TURKEY 34714

phone: +90 505 7958124, +90 2167730616
} 
materyalleri kullandınız?” şeklindedir. Bu soruya araştırmaya katılan öğretmenlerin verdikleri cevaplardan örnekler şu şekildedir:

\section{Ö.7. Akull tahta uygulamaları ve ders kitabı kullandım.}

\section{Ö.8. Ders kitabl, EBA'dan (test ...)}

\section{Ö.12. Ders kitabı, okuma kitapları, EBA, Okul fasikülleri}

Öğretmenlerin uzaktan öğretim süreçlerinde kullanılan materyallere yönelik cevaplarının konu başlıkları doğrultusunda analizi sonucunda oluşan verilere Tablo 3 ’te yer verilmiştir:

Tablo 3. Uzaktan öğretim süreçlerinde kullanılan materyaller

\begin{tabular}{lll}
\hline Konu alanı & Öğretmen & Frekans \\
\hline Online görüşme uygulamaları & Ö. $>1,20$ & 2 \\
Türkçe ders kitabı & Ö. $>1,2,3,5,6,7,8,9,10,11,12,13,14,16,17,18,19$ & 17 \\
Web araçları & Ö. $>1,4,5$ & 10 \\
Yardımcı kaynaklar & Ö. $>1,6,10,12,13,14,15,17,18,19$ & 13 \\
EBA & Ö. $>2,3,4,5,8,10,12,14,15,16,18,19,20$ & Frekans \\
\hline Konu alanı & Öğretmen & 2 \\
\hline Video, müzik vb. & Ö. $>2,6$ & 3 \\
Okuma kitapları & Ö. $>4,11,12$ & 2 \\
Akıllı tahta uygulamaları & Ö. $>7,9$ & 1 \\
TDK Sözlük & Ö. $>9$ & 8 \\
(https://sozluk.gov.tr/) & Ö. $>1,4,10,11,13,15,16,17$ & 1 \\
Elektronik kitap & $\ddot{O} .>10$ & \\
İnternet siteleri & & \\
\hline
\end{tabular}

Öğretmenlerin uzaktan öğretim süreçlerinde kullandıkları materyallere yönelik cevapları Tablo 3 doğrultusunda incelendiğinde en çok kullanılan materyalin Türkçe ders kitabı (F:17) olduğu görülmektedir. Bu duruma ek olarak EBA'yı on üç; test, fasikül, konu anlatımı gibi araçları kapsayan yardımcı kaynakları on; elektronik kitapları ise sekiz öğretmen uzaktan öğretim süreçlerinde kullandığını belirtmiştir. Web araçları ve okuma kitaplarının üçer; online görüşme uygulamalarının, video, müzik vb., akıllı tahta uygulamalarının ise ikişer öğretmen tarafından uzaktan öğretim süreçlerinde kullanıldığı görülmektedir. TDK Sözlük ve internet siteleri (F:1) ise araştırma konusu kapsamında frekansı en az olan materyaller olarak tespit edilmiştir.

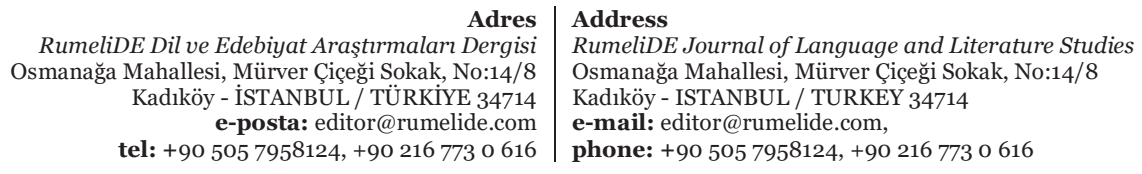


Öğretmen görüşme formunda yer alan ikinci soru "Uzaktan öğretim süreçlerinde Türkçe derslerinde kullandığınız materyallerin öğrencilerin akademik gelişimlerine etkilerini değerlendiriniz." şeklindedir. Bu soruya araştırmaya katılan öğretmenlerin verdikleri cevaplardan örnekler şu şekildedir:

Ö.14. Öğrencilerin konuyu öğrendikten sonra ellerinde kaynak olması konu tekrarı yapmasında çok etkili olmuştur.

Ö.16. Görsel anlamda destekleyici olması ve soru çeşitliliği sağlaması.

Ö.20. Derse kathlim olumlu yönde artt.

Öğretmenlerin uzaktan öğretim süreçlerinde kullanılan materyallerin akademik gelişime etkilerine yönelik cevaplarının konu başlıkları doğrultusunda analizi sonucunda oluşan verilere Tablo 4'te yer verilmiştir:

Tablo 4. Uzaktan öğretim süreçlerinde kullanılan materyallerin akademik gelişime etkileri

\begin{tabular}{lll}
\hline Konu alanı & Öğretmen & Frekans \\
\hline Olumlu etki & Ö. $>1,3,4,5,7,8,9,10,11,12,14,15,16,17,18,19,20$ & 17 \\
Olumsuz etki & Ö. $>1,2$ & 2 \\
\hline
\end{tabular}

Öğretmenlerin uzaktan öğretim süreçlerinde kullandıkları materyallerin akademik gelişime etkilerine yönelik cevapları Tablo 4 doğrultusunda incelendiğinde katılımcıların çoğunluğunun (F:17) uzaktan öğretim sürecinde kullanılan materyallerin akademik gelişim açısından olumlu niteliklerine vurgu yaptıkları tespit edilmiştir. Bu duruma ek olarak iki katılımcı uzaktan öğretim sürecinde kullanılan materyallerin akademik gelişim açısından olumsuz etkilerinin olduğunu belirtmiştir.

Öğretmen görüşme formunda yer alan üçüncü soru "Uzaktan öğretim süreçlerinde Türkçe derslerinde kullandığınız materyallerin ders işleyiş süreçlerinize etkilerini değerlendiriniz.” şeklindedir. Bu soruya araştırmaya katılan öğretmenlerin verdikleri cevaplardan örnekler şu şekildedir:

Ö.19. Bütün materyaller dijital ortamda kullanılmaya uygun olduğu için süreç verimli geçmiştir.

Ö.16. Ders süresinin verimini artırdı.

Ö.14. Dersimize katılımı artırmıştır. Öğrenmeyi olumlu etkilemişstir.

Öğretmenlerin uzaktan öğretim süreçlerinde kullanılan materyallerin ders işleyişs sürecine etkilerine yönelik cevaplarının konu başlıkları doğrultusunda analizi sonucunda oluşan verilere Tablo 5 'te yer verilmiştir:

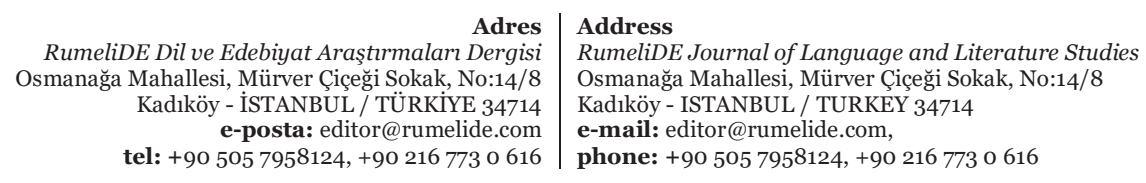


RumeliDE Dil ve Edebiyat Araştırmaları Dergisi 2022.26 (Şubat)/ 359

Uzaktan öğretim süreçlerinde kullanılan Türkçe dersi materyallerine yönelik öğretmen ve öğrenci görüşlerinin değerlendirilmesi / M. Fidan \& E. Sariaslan \& A. Yılmaz (350-368. s.)

Tablo 5. Uzaktan öğretim süreçlerinde kullanılan materyallerin ders işleyişs sürecine etkileri

\begin{tabular}{lll}
\hline Konu alanı & Öğretmen & Frekans \\
\hline $\begin{array}{l}\text { Web araçlarının yazma becerisine olumlu } \\
\text { katkısı }\end{array}$ & Ö. $>1$ & 1 \\
E - dokümanlarda bağlantı sorunu & Ö. $>2$ & 1 \\
Verilere erişim kolaylı̆̆ı & Ö. $>3,19$ & 2 \\
Verimli olma, olumlu motivasyon sağlama & Ö. $>3,4,5,7,9,10,11,14,16,19,20$ & 11 \\
$\begin{array}{l}\text { Ölçme-değerlendirmeye olumlu katkı } \\
\text { sağlama }\end{array}$ & Ö. $>6,8,12,18$ & 4 \\
Çoklu duyusal ortam oluşturabilme & $\ddot{O} .>8,15,17$ & 3 \\
\hline
\end{tabular}

Öğretmenlerin uzaktan öğretim süreçlerinde kullandıkları materyallerin ders işleyiş sürecine etkilerine yönelik cevapları Tablo 5 doğrultusunda incelendiğinde, akademik gelişime benzer verilerin olduğu görülmektedir. $\mathrm{Bu}$ açıdan cevaplar değerlendirildiğinde Türkçe derslerinde uzaktan öğretim süreçlerinde kullanılan materyallerin ders işleyiş süreci açısından en çok verimli olma, olumlu motivasyon sağlama yönlerine (F:11) katılımcılar tarafından vurgu yapıldığı görülmektedir. Bu materyallerin ayrıca ölçme-değerlendirme (F:4), çoklu duyusal ortam oluşturabilme (F:3), verilere erişim kolaylığı sağlama (F:2),yazma becerisine katkı (F:1) gibi olumlu özelliklerine de katılımcılar tarafından değinilmiştir. Bir katılımcı ise uzaktan öğretim süreçlerinde kullanılan dokümanlarda bağlantı sorununun ders işleyiş sürecine olumsuz etkilerinin olduğunu belirtmiştir.

Öğretmen görüşme formunda yer alan dördüncü soru "Uzaktan öğretim süreçlerinde Türkçe derslerinde kullanılacak materyaller size göre hangi özelliklere sahip olmalıdır?” şeklindedir. Bu soruya araştırmaya katılan öğretmenlerin verdikleri cevaplardan örnekler şu şekildedir:

Ö.14. Seviyeye uygun şekilde hazırlanarak MEB'e uygun soru ve etkinlikler olmahdır.

Ö.13. Görsel kaynaklarla desteklenmelidir.

Ö.7. Dijital ortamda rahat kullanılabilecek nitelikte olmalıdır.

Öğretmenlerin uzaktan öğretim süreçlerinde kullanılacak materyallerde bulunması gereken özelliklere yönelik değerlendirmelerinin konu başlıkları doğrultusunda analizi sonucunda oluşan verilere Tablo 6'da yer verilmiştir:

Tablo 6. Uzaktan öğretim süreçlerinde kullanılacak materyallerde bulunması gereken özellikler

\begin{tabular}{|c|c|c|c|}
\hline Konu alanı & \multicolumn{2}{|l|}{ Öğretmen } & Frekans \\
\hline Öğrenciye görelilik & \multicolumn{2}{|l|}{ Ö. $>8,12,14$} & 3 \\
\hline Kazanımları karşılayabilme & \multicolumn{2}{|l|}{ Ö. > 1, 3, 14, 18} & 4 \\
\hline $\begin{array}{l}\text { Gelişmiş içerik (Çoklu duyusal } \\
\text { ortam sağlama) }\end{array}$ & \multicolumn{2}{|l|}{ Ö. > 1, 4, 5, 12, 13, 17, 19} & 7 \\
\hline \multicolumn{2}{|c|}{$\begin{array}{r}\text { Adres } \\
\text { RumeliDE Dil ve Edebiyat Arassttrmaları Dergisi } \\
\text { Osmanağa Mahallesi, Mürver Ciçeği Sokak, No:14/8 } \\
\text { Kadıköy - İSTANBUL / TÜRKIYYE } 34714 \\
\text { e-posta: editor@rumelide.com } \\
\text { tel: }+90 \text { 505 7958124, +90 } 216773 \text { o } 616\end{array}$} & $\begin{array}{l}\text { Address } \\
\text { RumeliDE Journal of Language and Literature Studies } \\
\text { Osmanağa Mahallesi, Mürver Ciçeği Sokak, No:14/8 } \\
\text { Kadkköy - ISTANBUL / TURKEY } 34714 \\
\text { e-mail: editor@rumelide.com, } \\
\text { phone: +90 } 505 \text { 7958124, +90 } 216773 \text { o } 616\end{array}$ & \\
\hline
\end{tabular}


360 / RumeliDE Journal of Language and Literature Studies 2022.26 (February)

Evaluation of teacher and student views on Turkish lesson materials used in distance education processes / M. Fidan \& E. Sarıaslan \& A. Yilmaz (pp. 350-368)

Teknoloji ile uyumluluk, etkileşimli olma

Dikkat çekicilik

Geri bildirim sağlayabilme

Açıklık, anlaşılırlık
Ö. $>2,4,5,7,16,20$

Ö. > 3, 6, 9, 11, 12

Ö. > 6

Ö. > 10,15
6

Öğretmenlerin uzaktan öğretim süreçlerinde kullanılacak materyallerde bulunması gereken özelliklere yönelik cevapları Tablo 6 doğrultusunda incelendiğinde, çoklu duyusal ortam sağlama şeklinde de ifade edilebilecek gelişmiş içeriklerinin olmasının (F:7) ve teknoloji ile uyumluluk, etkileşimli olmanın (F:6) en çok değinilen özellikler olduğu görülmektedir. Bu duruma ek olarak dikkat çekicilik (F:5), kazanımları karşılayabilme (F:4), öğrenciye görelilik (F:3), açıklık, anlaşılırlık (F:2) ve geri bildirim sağlayabilme (F:1) özelliklerine de katılımcılar tarafından vurgu yapıldığı tespit edilmiştir.

Öğretmen görüşme formunda yer alan beşinci soru "Uzaktan öğretim süreçlerinde Türkçe derslerinde kullanılmasının uygun olduğunu düşündüğünüz/önerdiğiniz materyaller nelerdir? Açıklayınız." şeklindedir. Bu soruya araştırmaya katılan öğretmenlerin verdikleri cevaplardan örnekler şu şekildedir:

\section{Ö.20. Ders kitaplarmmn etkileşimli olması}

\section{Ö.1. Web 2.o araçları}

\section{Ö.3. Ĕ̆itici web tabanh oyunlar}

Öğretmenlerin uzaktan öğretim süreçlerinde kullanılmasını uygun gördükleri materyallere yönelik önerilerinin konu başlıkları doğrultusunda analizi sonucunda oluşan verilere Tablo 7'de yer verilmiştir:

Tablo 7. Uzaktan öğretim süreçlerinde kullanılması uygun materyal önerileri

\begin{tabular}{llc}
\hline Konu alanı & Öğretmen & Frekans \\
\hline Web araçları & Ö. $>1,3$ & 2 \\
Video, müzik vb. & Ö. $>1,3,6,9,15,19$ & 6 \\
Oyunlaştırma & Ö. $>2$ & 1 \\
EBA & Ö. $>4,5$ & 2 \\
Yardımcı kaynaklar & $\ddot{.}>9,17,18$ & 3 \\
Elektronik kitap & Ö. $>10$ & 1 \\
Etkileşimli Türkçe ders kitabı & Ö. $>20$ & 1 \\
\hline
\end{tabular}

Öğretmenlerin uzaktan öğretim süreçlerinde kullanılması uygun materyal önerilerine yönelik cevapları Tablo 7 doğrultusunda incelendiğinde en fazla değinilen materyallerin video, müzik vb. (F:6) türünde

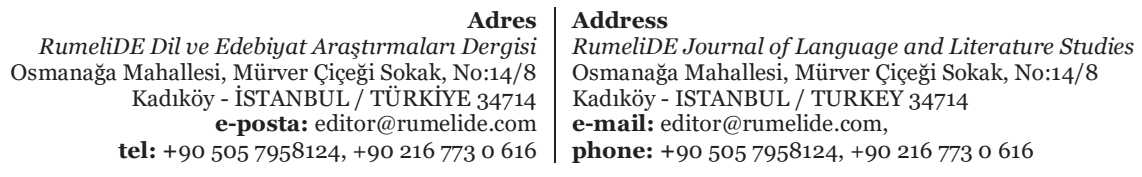


olduğu görülmüştür. Bu durama ek olarak sırasıyla yardımcı kaynaklar (F:3), web araçları (F:2), oyunlaştırma (F:1), elektronik kitap (F:1) ve etkileşimli Türkçe ders kitabının (F:1) araştırmaya katılan Türkçe öğretmenleri tarafından uzaktan öğretim süreçleri için önerilen kaynaklar olduğu tespit edilmiştir.

\section{2. Öğrencilerin Türkçe dersinde uzaktan öğretim süreçlerinde kullanılan materyallere yönelik görüşleri}

Araştırma sürecinde kullanılan öğrenci görüşme formunda yer alan ilk soru "Uzaktan öğretim döneminde Türkçe derslerinde öğretmenleriniz hangi tür materyalleri kullandılar? Açıklayınız." şeklindedir. Bu soruya araştırmaya katılan öğrencilerin verdikleri cevaplardan örnekler şu şekildedir:

Ör. 44. EBA üzerinden e-kitap çoğunluğu ile ders işledik.

Ör. 45. Ders kitabl, online kitaplar, EBA, bilgisayar

Ör. 54. Bilgisayar, e-kitap, ders kitabı

Araştırmaya katılan öğrencilerin uzaktan öğretim süreçlerinde kullanılan materyallere yönelik görüşlerinin konu başlıkları doğrultusunda analizi sonucunda oluşan verilere Tablo 8'de yer verilmiştir:

Tablo 8. Uzaktan öğretim süreçlerinde kullanılan materyaller

\begin{tabular}{|c|c|c|c|}
\hline Konu alanı & \multicolumn{2}{|l|}{ Öğrenci } & Frekans \\
\hline Web araçları & \multicolumn{2}{|c|}{$\begin{array}{l}\text { Ör. }>1,2,3,4,5,6,7,8,9,10,11,12,13,14,15,16,17,18,19,20, \\
21,24,25,26,27,28,29,30,35,37,38,70,71,73,74,77,78,81, \\
82,83,85,86,87,88\end{array}$} & 44 \\
\hline Elektronik kitap & \multicolumn{2}{|c|}{ Ör. > 1, 6, 13, 25, 27, 28, 32, 37, 44, 45, 50, 54, 55, 58, 59, 63} & 16 \\
\hline Online görüşme uygulamaları & \multicolumn{2}{|c|}{ Ör. > 3, 7, 18, 25, 27, 64, 67} & 7 \\
\hline Yardımcı kaynaklar & \multicolumn{2}{|c|}{ Ör. $>4,5,8,26,29,30,53,56,57,61,62$} & 11 \\
\hline Sosyal medya uygulamaları & \multicolumn{2}{|c|}{ Ör. $>6,8,24,28,29,39,40,42,43,49,50$} & 11 \\
\hline EBA & \multicolumn{2}{|c|}{$\begin{array}{l}\text { Ör. > 7, 25, 27, 28, 43, 44, 45, 49, 58, 59, 64, 68, 69, 70, 71, 72, 73, } \\
74,75,79,81,82,83,84,85,86,87,88,89,90\end{array}$} & 30 \\
\hline $\begin{array}{l}\text { TDK Sözlük } \\
\text { (https://sozluk.gov.tr/) }\end{array}$ & \multicolumn{2}{|c|}{ Ör. $>7,39,58,59,73,74,78,82,89$} & 9 \\
\hline Video, müzik vb. & \multicolumn{2}{|c|}{ Ör. > 9, 26, 30, 31, 32, 33, 36, 59, 63} & 9 \\
\hline Sunu (Pdf, Ppt, Word vb.) & \multicolumn{2}{|c|}{ Ör. > 9, 28, 38, 42, 49, 53, 58, 59, 64} & 9 \\
\hline Akıllı tahta uygulamaları & \multicolumn{2}{|c|}{ Ör. > 5, 7, 10, 11, 15, 20, 21, 26, 28, 29, 31, 33, 35, 36} & 14 \\
\hline İnternet siteleri & \multicolumn{2}{|c|}{ Ör. > 22, 50, 52, 56, 57, 62, 75, 76, 80, 82, 88, 90} & 12 \\
\hline Oyunlar & \multicolumn{2}{|l|}{ Ör. > 36} & 1 \\
\hline $\begin{array}{r}\text { RumeliDE Dil ve E } \\
\text { Osmanağa Mahallesi, } \\
\text { Kadıköy - } \\
\text { e } \\
\text { tel: }+905\end{array}$ & $\begin{array}{l}\text { Adres } \\
\text { biyat Arasttrmaları Dergisi } \\
\text { ürver Ciçeği Sokak, No:14/8 } \\
\text { TANBUL/ TÜRKIYY } 34714 \\
\text { osta: editor@rumelide.com } \\
7958124,+90216773 \text { o } 616\end{array}$ & $\begin{array}{l}\text { Address } \\
\text { RumeliDE Journal of Language and Literature Studies } \\
\text { Osmanağa Mahallesi, Mürver Ciçę̆i Sokak, No:14/8 } \\
\text { Kadlköy - ISTANBUL / TURKEY } 34714 \\
\text { e-mail: editor@rumelide.com, } \\
\text { phone: +90 } 505 \text { 7958124, +90 } 216773 \text { o } 616\end{array}$ & \\
\hline
\end{tabular}


362 / RumeliDE Journal of Language and Literature Studies 2022.26 (February)

Evaluation of teacher and student views on Turkish lesson materials used in distance education processes / M. Fidan \& E. Sarıaslan \& A. Yilmaz (pp. 350-368)

Kelime defteri

Türkçe ders kitabı
Ör. $>39$

Ör. > 30, 31, 32, 39, 40, 42, 43, 45, 52, 53, 54, 55, 59, 61, 66, 68, 69, 70, 71, 36 $72,73,74,75,76,77,78,79,80,81,82,83,84,86,87,89,90$

Araştırmaya katılan öğrencilerin uzaktan öğretim süreçlerinde kullanılan materyallere yönelik cevapları Tablo 8 doğrultusunda incelendiğinde en çok kullanılan materyallerin web araçları (F:44) ve Türkçe ders kitabı (F:36) olduğu görülmektedir. Bu duruma ek olarak EBA'nın (F:30) da diğer materyallere kıyasla uzaktan öğretim süreçlerinde daha fazla kullanıldığı öğrencilerin görüşleri doğrultusunda tespit edilmiştir. Ayrıca elektronik kitap (F:16) ve akıllı tahta uygulamaları (F:14) da bu doğrultuda sıralanabilir. Uzaktan öğretim süreçlerinde kullanılan diğer materyaller ise; internet siteleri (F:12), yardımcı kaynaklar (F:11), sosyal medya uygulamaları (F:11), TDK Sözlük (F:9), video, müzik vb.(F:9), sunu (F:9) ve online görüşme uygulamaları (F:7) şeklinde sıralanabilir. Son olarak birer öğrenci, uzaktan öğretimde kullanılan materyaller arasında oyunları ve kelime defterini sıralamıştır.

Araştırma sürecinde kullanılan öğrenci görüşme formunda yer alan ikinci soru "Uzaktan öğretim döneminde Türkçe derslerinde öğretmenlerinizin kullandı̆̆ı materyalleri değerlendiriniz.” şeklindedir. Bu soruya araştırmaya katılan öğrencilerin verdikleri cevaplardan örnekler şu şekildedir:

Ör. 42. Hepsi işimize yarayan materyallerdi, hepsi kullanışhydı.

Ör. 54. Benim öğrenmemi zorlaştırdı. Çünkü uzaktan zor oluyordu.

Ör. 9o. Çok iyi.

Araştırmaya katılan öğrencilerin uzaktan öğretim süreçlerinde kullanılan materyallere yönelik değerlendirmelerinin konu başlıkları doğrultusunda analizi sonucunda oluşan verilere Tablo 9'da yer verilmiştir:

Tablo 9. Uzaktan öğretim süreçlerinde kullanılan materyallere yönelik değerlendirme

\begin{tabular}{|c|c|c|c|}
\hline Konu alanı & \multicolumn{2}{|l|}{ Öğrenci } & Frekans \\
\hline Web araçlarının olumlu etkisi & \multicolumn{2}{|c|}{ Ör. > 1, 2, 4, 5, 10,12, 13, 14, 17, 18, 19, 20, 28, 29, 30, 34, 35, 37} & 18 \\
\hline Yardımcı kaynakların olumlu etkisi & \multicolumn{2}{|l|}{ Ör. $>4,53,74$} & 3 \\
\hline Elektronik kitapların olumlu etkisi & \multicolumn{2}{|l|}{ Ör. $>6,13,37$} & 3 \\
\hline $\begin{array}{l}\text { Türkçe ders kitabının verimliliğe } \\
\text { etkisi }\end{array}$ & \multicolumn{2}{|l|}{ Ör. > 8, 29, 31, 40, 43} & 5 \\
\hline $\begin{array}{l}\text { Kullanılan materyallerin genel } \\
\text { olarak olumlu etkisi }\end{array}$ & \multicolumn{2}{|c|}{$\begin{array}{l}\text { Ör. }>7,9,11,15,16,21,22,23,25,26,27,32,33,42,44,49,58, \\
63,64,66,67,68,69,70,71,73,76,77,78,79,80,81,82,83,84, \\
85,86,87,88,89,90\end{array}$} & 41 \\
\hline Video, müzik vb.nin olumlu etkisi & \multicolumn{2}{|l|}{ Ör. > 10, 20, 24, 31} & 4 \\
\hline $\begin{array}{l}\text { Akıllı tahta uygulamalarının } \\
\text { olumlu etkisi }\end{array}$ & \multicolumn{2}{|l|}{ Ör. $>20,34$} & 2 \\
\hline \multicolumn{2}{|c|}{$\begin{array}{r}\text { Adres } \\
\text { RumeliDE Dil ve Edebiyat Arașttrmaları Dergisi } \\
\text { Osmanağa Mahallesi, Mürver Ciceği Sokak, No:14/8 } \\
\text { Kadıköy - İSTANBUL / TÜRKIYYE } 34714 \\
\text { e-posta: editor@rumelide.com } \\
\text { tel: }+90 \text { 505 7958124, +90 } 216773 \text { o } 616\end{array}$} & $\begin{array}{l}\text { Address } \\
\text { RumeliDE Journal of Language and Literature Studies } \\
\text { Osmanağa Mahallesi, Mürver Ciceği Sokak, No:14/8 } \\
\text { Kadıköy - ISTANBUL/ TURKEY } 34714 \\
\text { e-mail: editor@rumelide.com, } \\
\text { phone: + } 90 \text { 505 } 5958124,+90216773 \text { o } 616\end{array}$ & \\
\hline
\end{tabular}




\begin{tabular}{|c|c|c|}
\hline $\begin{array}{l}\text { Sunuların (Pdf, Ppt, Word vb.) } \\
\text { olumlu etkisi }\end{array}$ & Ör. > 38 & 1 \\
\hline Web araçlarının olumsuz etkisi & Ör. > 24, 53 & 2 \\
\hline Fiziksel rahatsızlık & Ör. > 39, 50, 51, 55, 57, 61, 62, 66 & 8 \\
\hline $\begin{array}{l}\text { Kullanılan materyallerin yetersiz } \\
\text { bulunması (geliştirilmesi } \\
\text { gerekliliği) }\end{array}$ & Ör. $>41,45,48,52,60,72$ & 6 \\
\hline $\begin{array}{l}\text { Kullanılan materyallerin } \\
\text { öğrenmeye olumsuz etkisi }\end{array}$ & Ör. > 54, 65, 75 & 3 \\
\hline
\end{tabular}

Araştırmaya katılan öğrencilerin, uzaktan öğretim süreçlerinde kullanılan materyallere yönelik değerlendirmeleri incelendiğinde materyallerin genel olarak olumlu etkisinin (F:41) ön plana çıktığ görülmektedir. Bu genel sonuca ek olarak öğrenciler, materyaller özelinde de çeşitli değerlendirmeler yapmışlardır. Bu doğrultuda web araçlarının olumlu etkisi (F:18) materyallerin özel olarak değerlendirilmesinde öğrencilerin en çok değindiği konu alanıdır. Ayrıca Türkçe ders kitabının verimliliğe etkisi (F:5), video, müzik vb.nin olumlu etkisi (F:4), yardımcı kaynakların olumlu etkisi (F:3), elektronik kitapların olumlu etkisi (F:3), akıllı tahta uygulamalarının olumlu etkisi (F:2), sunuların olumlu etkisi (F:1) öğrenciler tarafından sıralanan materyallerin katkılarıdır. Uzaktan öğretim süreçlerinde kullanılan materyallerin olumlu özelliklerine ek olarak bu süreçte yaşanılan fiziksel rahatsızlıklar (F:8), materyallerin yetersizliği (F:6), materyallerin öğrenmeye olumsuz etkisi (F:3), web araçlarının olumsuz etkisi (F:2) konularında ise öğrencilerin uzaktan öğretim süreçlerine yönelik eleştirel düşüncelerini belirttikleri görülmüştür.

Araştırma sürecinde kullanılan öğrenci görüşme formunda yer alan üçüncü soru "Size göre uzaktan öğretimde kullanılacak Türkçe dersi materyallerinin hangi özellikleri olmalıdır? Açılayınız.” şeklindedir. Bu soruya araştırmaya katılan öğrencilerin verdikleri cevaplardan örnekler şu şekildedir:

Ör.3. Özellikle bazı faydah alşkanlıkları teşvik edici olmalıdır.

Ör.35. Kullanışh

Ör.26. Anlaşlabilir, rahat kullanıml, zahmetsiz.

Araştırmaya katılan öğrencilerin uzaktan öğretim süreçlerinde kullanılacak materyallerde bulunması gereken özelliklere yönelik değerlendirmelerinin konu başlıkları doğrultusunda analizi sonucunda oluşan verilere Tablo 10'da yer verilmiştir:

Tablo 10. Uzaktan öğretim süreçlerinde kullanılacak materyallerde bulunması gereken özellikler

\begin{tabular}{llc}
\hline Konu alanı & Öğrenci & Frekans \\
\hline $\begin{array}{l}\text { Erişim kolaylığının } \\
\text { olması }\end{array}$ & Ör. $>1,5,17,42,59$ & 5 \\
$\begin{array}{l}\text { Olumlu davranışları } \\
\text { teşvik edicilik }\end{array}$ & Ör. $>3$ & 1 \\
$\begin{array}{l}\text { Kendini ifade etmeye } \\
\text { katkı sağlaması }\end{array}$ & Ör. > 5, 7, 10, 13, 29, 38, 39, 40, 49 & 9
\end{tabular}

\footnotetext{
\begin{tabular}{r|l} 
Adres & Address \\
RumeliDE Dil ve Edebiyat Araştırmaları Dergisi & RumeliDE Journal of Language and Literature Studies
\end{tabular}

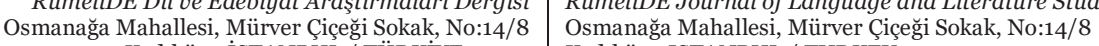
Kadıköy - İSTANBUL / TÜRKIYE 34714 Kadıköy - ISTANBUL / TURKEY 34714

e-posta: editor@rumelide.com e-mail: editor@rumelide.com,

phone: +90 505 7958124, +90 2167730616
} 
364 / RumeliDE Journal of Language and Literature Studies 2022.26 (February)

Evaluation of teacher and student views on Turkish lesson materials used in distance education processes / M. Fidan \& E. Sariaslan \& A. Yllmaz (pp. 350-368)

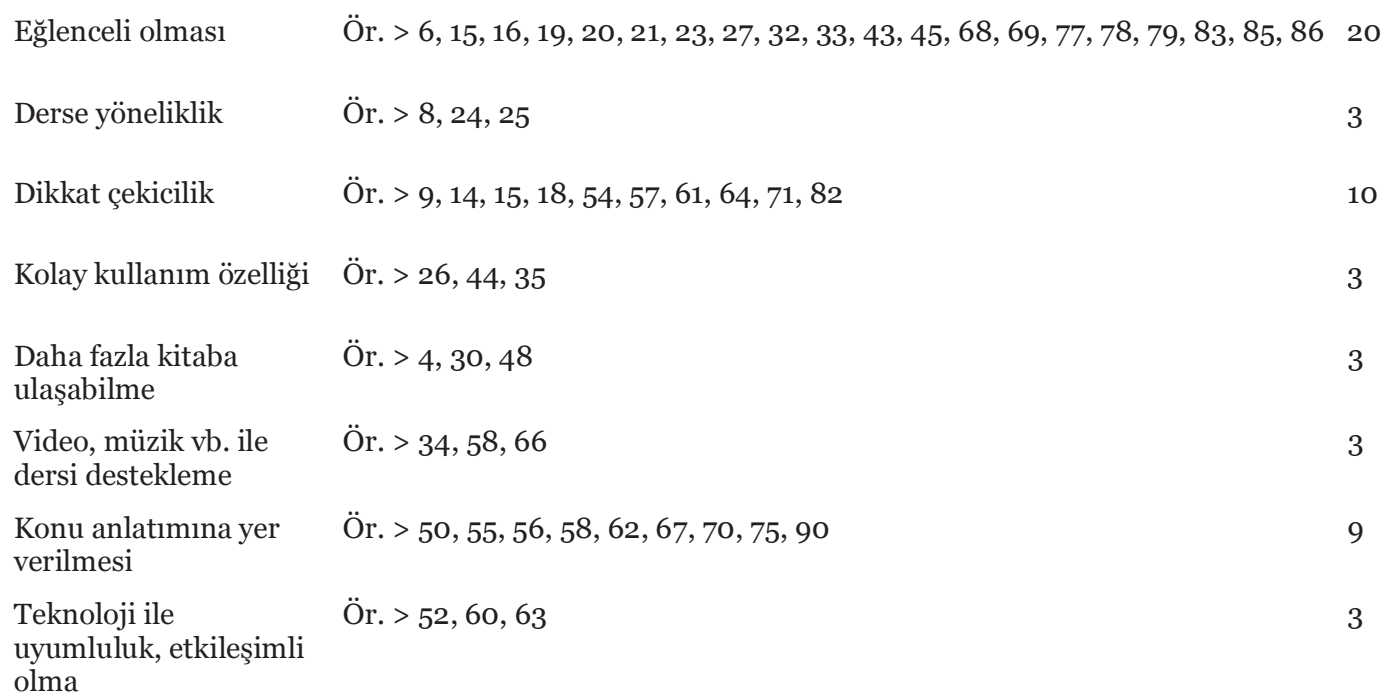

Araştırmaya katılan öğrencilerin uzaktan öğretim süreçlerinde kullanılacak materyallerde bulunması gereken özelliklere yönelik değerlendirmeleri incelendiğinde en çok değinilen konu, materyalin eğlenceli olmasıdır (F:20). Ayrıca bu materyallerde dikkat çekicilik (F:10), kendini ifade etmeye katkı sağlama (F:9), konu anlatımına yer verilmesi (F:9) gibi özelliklerin bulunması gerektiği de öğrenciler tarafından daha fazla değinilen konu başlıkları olarak sıralanabilir. Erişim kolaylığının olması (F:5) özelliğine ek olarak, üçer öğrenci uzaktan öğretim süreçlerinde kullanılan materyallerde derse yöneliklik; kolay kullanım; daha fazla kitaba ulaşabilme; video, müzik vb. ile dersi destekleme; teknoloji ile uyumluluk; etkileşimli olma özelliklerinin de olması gerektiğini belirtmiştir. Bir öğrenci ise materyallerin olumlu davranışları teşvik edici olması gerektiğini ifade etmiştir.

Araştırma sürecinde kullanılan öğrenci görüşme formunda yer alan dördüncü soru "Uzaktan öğretimde kullanılacak Türkçe dersi materyallerine yönelik önerileriniz nelerdir? Belirtiniz.” şeklindedir. Bu soruya araştırmaya katılan öğrencilerin verdikleri cevaplardan örnekler şu şekildedir:

Ör.9. Web 2.o araçları

Ör. 13. Daha eğlenceli dersler için müzikle, ders yönelik oyunlarla ders dikkat çekici hale gelebilir.

Ör. 17. Bence görsel açıdan zengin kullanılabilir.

Ör. 85. EBA, kitaplar, test kitapları

Araştırmaya katılan öğrencilerin uzaktan öğretim süreçlerinde kullanılmasının uygun olduğunu düşündükleri materyallere yönelik önerilerinin konu başlıkları doğrultusunda analizi sonucunda oluşan verilere Tablo 11'de yer verilmiştir:

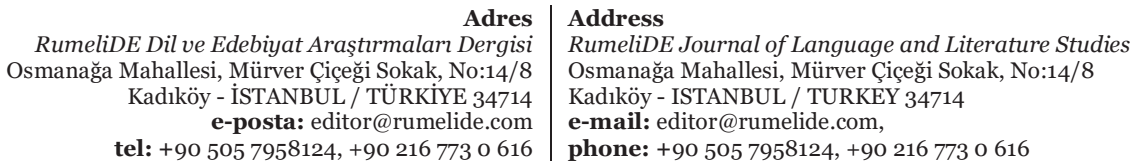


RumeliDE Dil ve Edebiyat Araştırmaları Dergisi 2022.26 (Şubat)/ 365

Uzaktan öğretim süreçlerinde kullanılan Türkçe dersi materyallerine yönelik öğretmen ve öğrenci görüşlerinin değerlendirilmesi / M. Fidan \& E. Sariaslan \& A. Yılmaz (350-368. s.)

Tablo 11. Uzaktan öğretim süreçlerinde kullanılması uygun materyal önerileri

\begin{tabular}{llc}
\hline Konu alanı & Öğrenci & Frekans \\
\hline Web araçları & Ör. $>1,3,7,9,42$ & 5 \\
EBA & Ör. $>42,62,85,79$ & 4 \\
Sosyal medya uygulamaları & Ör. $>4,8$ & 11 \\
$\begin{array}{l}\text { Video, müzik vb. (Görsel ve/veya } \\
\text { işitsel ögelerle desteklenme) }\end{array}$ & Ör. $>9,13,17,18,31,33,34,53,56,64,77$ & 6 \\
Kolay kullanılır materyaller & Ör. $>3,4,26,35,48,66$ & 15 \\
Yardımcı kaynaklar & Ör. $>6,32,40,50,52,52,53,55,58,59,62,68,69,75,85$ & 3 \\
Oyun temelli etkinlikler & Ör. $>5,13,88$ & 5 \\
Türkçe ders kitabı & Ör. $>8,36,39,44,90$ & 3 \\
TDK Sözlük & Ör. $>19,21,39$ & 5 \\
Akıllı tahta uygulamaları & Ör. $>83,86,87,46,66$ & 5 \\
\hline
\end{tabular}

Araştırmaya katılan öğrencilerin uzaktan öğretim süreçlerinde kullanılmasının uygun olduğunu düşündükleri materyallere yönelik önerileri değerlendirildiğinde en çok önerilen materyallerin yardımcı kaynaklar (F:15) ve video, müzik vb. (F:11) olduğu söylenilebilir. Kolay kullanılır materyallere (F:6) ek olarak; web araçları, Türkçe ders kitabı, akıllı tahta uygulamaları (F:5) sıralı olarak öğrenciler tarafından en çok önerilen materyallerdir. Ayrıca araştırmaya katılan dört öğrencinin EBA platformunu, üçer öğrencinin ise oyun temelli etkinlikler ile TDK Sözlük’ü önerdiği tespit edilmiştir. Son olarak sosyal medya uygulamaları (F:2) da önerilen materyaller arasında yer almaktadır.

\section{Sonuç ve tartışma}

$\mathrm{Bu}$ araştırmada uzaktan öğretim süreçlerinde kullanılan Türkçe dersi materyallerine yönelik öğretmenlerin ve öğrencilerin görüşlerine başvurulmuştur. Elde edilen veriler konu alanları açısından analiz edilmiştir. Bu doğrultuda araştırmada öğretmen ve öğrenci görüşleri vasıtasıyla elde edilen sonuçlar sıralanmıştır:

Uzaktan öğretim süreçlerinde kullanılan materyaller araştırmaya katılan Türkçe öğretmenlerinin görüşleri doğrultusunda değerlendirildiğinde en çok kullanılan materyallerin Türkçe ders kitabı, EBA platformu, yardımcı kaynaklar olduğu görülmüsştür. Aynı yönde öğrencilerin cevapları değerlendirildiğinde ise web araçları, Türkçe ders kitabı ve EBA platformu ön plana çıkmaktadır. Bu konuda özellikle EBA ve web araçları ile ilgili çalışmalar da bulunmaktadır (Kaplan, Gülden, 2021; Kavan, Adıgüzel, 2021). Öğretmen ve öğrenci görüşleri bu doğrultuda karşlaştırıldığında Türkçe ders kitabı ve EBA platformu açısından sonuçların benzer olduğu sonucuna ulaşılmıştır. Sonuçlar bu doğrultuda değerlendirildiğinde Türkçe ders kitapları, yüz yüze eğitimde olduğu gibi doğal olarak uzaktan eğitim süreçlerinde de sıklıkla kullanılmıştır. Nitekim okullarda akıllı tahta kullanımının yaygınlaşmasıyla birlikte ders kitaplarının e-dosya biçimindeki sürümleri de bu süreç boyunca kullanılmıştır. $\mathrm{Bu}$ durumun öğretmenlere uzaktan eğitim süreçlerinde materyal konusunda katkı

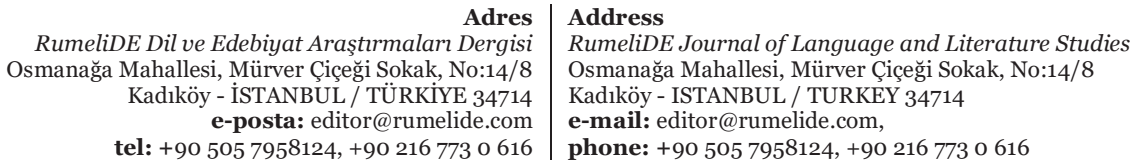


sağladığı söylenilebilir. Ders kitaplarının teknoloji ile daha fazla uyumlu olmasının, dersin ilgi çekiciliğine olumlu yönde katkı sağlaması mümkündür. Nitekim bu konuda Karagöl (2021:149) uzaktan öğretim süreçlerinde kullanılan temel materyallerden biri olan ders kitaplarının etkileşimli olması gerektiğini belirtmiştir. Bu durumun (ders kitaplarının etkileşimli olmasının), akıllı tahta kullanımı doğrultusunda yüz yüze eğitim süreçlerinde de olumlu etkilerinin olması muhtemeldir. EBA platformu için de benzer durumdan söz etmek mümkündür. Bu doğrultuda Türkçe ders kitapları ve EBA platformunda yer alan çeşitli etkinlikler uzaktan öğretim süreçlerinde en çok tercih edilen materyaller olmuştur. Ayrıca web araçları vasıtasıyla oluşturulan materyallerin de Türkçe derslerinde uzaktan öğretim süreçlerinde diğer materyallere göre daha fazla kullanıldığı söylenilebilir.

Araştırmaya katılan Türkçe öğretmenlerinin çoğunluğunun uzaktan öğretim sürecinde kullanılan materyalleri akademik gelişim açısından olumlu olarak niteledikleri tespit edilmiştir. Bu materyallerin ders işleyiş sürecine etkilerine yönelik cevaplar değerlendirildiğinde verimli olma, olumlu motivasyon sağlama yönlerine öğretmenlerin vurgu yaptı̆̆ görülmüştür. Benzer şekilde öğrencilerin uzaktan öğretim süreçlerinde kullanılan materyallere yönelik değerlendirmeleri incelendiğinde, kullanılan materyallerin genel olarak olumlu etkisinin ön plana çıtı̆̆̆ sonucuna ulaşılmıştır. Bu durum uzaktan öğretim süreçlerinde kullanılan materyallere yönelik öğretmen ve öğrencilerde olumlu bir düşüncenin oluştuğunun göstergesidir. Uzaktan öğretim süreçlerinin internet tabanlı uygulamalar vasitasıyla yürütülmesi, bu uygulamalarla uyumlu materyal geliştirilmesini gündeme getirmiştir. Konuya Türkçenin yabancı dil olarak öğretimi açısından yaklaşan Şengül (2021:217) uzaktan öğretim süreçlerinde teknolojik materyallerin kullanımının arttığını ve bu materyallerin önemli bir içerik aktarım aracı olduğunu belirtmektedir. Bilişim teknolojilerinin ve bu teknolojilerin temel uygulama alanı olan internetin eğitim öğretim ortamında kullanılmasında, uzaktan öğretim süreçlerinin, özellikle materyal geliştirmeye teşvik yönünden, olumlu etkilerinin bulunduğu görülmektedir. Bu durum eğitim süreçlerinde kullanılacak materyallerde hangi özelliklerin bulunması gerektiği sorusunu ön plana çıkarmaktadır. Nitekim bu araştırmanın ilgili sonuçları da materyallerde bulunması gereken özelliklerin bir nevi göstergesi niteliğindedir. Bu doğrultuda Türkçe derslerinde uzaktan öğretim süreçlerinde kullanılacak materyallerde bulunması gereken özelliklere yönelik öğretmenlerin cevapları değerlendirildiğinde, materyallerin gelişmiş içeriklerinin olmasına, teknoloji ile uyumluluğuna, dikkat çekici olmasına daha çok vurgu yapıldığı tespit edilmiştir. Öğrencilerin ise bu konuda en fazla eğlenceli olma özelliğine değindikleri görülmüş ve buna ek olarak öğretmenlerin cevapları ile benzer olarak dikkat çekicilik bir diğer ön plana çıkan özelliktir. Ancak bu aşamada öğretmenlerin hem materyal tasarımı hem de teknoloji bilgisi yönünden yetkinliklerinin gelişmiş olması beklenilmektedir. Bu konuda Göçen Kabaran ve Uşun (2021: 300-301) dijital materyal üretebilmenin öğretmenler açısından bir yeterlilik olduğunu belirtmektedirler. Türkçe eğitimi açısından dijital yetkinliğin durumuna yönelik araştırmada da mevcut durumunun çeşitli açılardan incelendiği görülmektedir (Geçgel, Kana, Eren, 2020). Duman ve Yurdakul (2021: 436) da yabancılara Türkçe öğretimi açısından bu yetkinliğe vurgu yapmaktadır. Ayrıca teknolojide yetkinlik, dijital yetkinlik gibi becerilerin, öğretim programlarının temelinde bulunduğu da unutulmamalıdır (MEB, 2019). Branşlar özelinde çevrimiçi eğitimler vasıtasıyla teknoloji ile uyumlu materyal hazırlama konusunda öğretmenlere çeşitli rehberlik faaliyetlerinin yapılmasının bu yönde olumlu katkılarının olacağı düşünülmektedir.

Öğretmenlerin Türkçe derslerinde uzaktan öğretim süreçlerinde kullanılması uygun materyal önerileri değerlendirildiğinde en çok vurgulanan önerinin video, müzik vb. temelli materyaller olduğu tespit edilmiştir. Ayrıca öğrencilerin öğretmenlerle benzer olarak en çok değindikleri ikinci materyal önerilerinin video, müzik vb. temelli materyaller olduğu sonucuna ulaşılmıştır. Özellikle video, müzik vb. temelli materyallerin öğrencilerin çoklu duyularına hitap etmesi, bu özellikteki materyallerin ilgi çekiciliğine ve

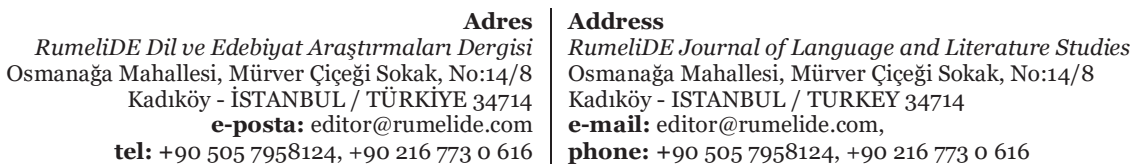


etkililiğine önemli katkılar sağlayabilmektedir. Öğrencilerin en çok önerdiği materyal ise yardımcı kaynaklardır. Bu durum özellikle öğrenciler açısından önemli görülmektedir. Çünkü öğrencilerin uzaktan öğretim süreçlerinde kullanılmasını en çok önerdikleri materyalin yardımcı kaynaklar olması, bu yönde ders kitaplarına ek olarak öğretmenlerin konuları destekleyici çeşitli materyaller tasarlamasını gerekli kılmaktadır. Nitekim araştırmaya katılan bazı öğretmenler de bu bağlamda kendi okullarının hazırladığı fasiküllerden yararlandıklarını belirtmişlerdir. Ancak bu türden materyallerin tasarımında öğretim programları ile uyumluluk, ücretsiz erişim gibi temel özelliklerin bulunması gerektiği göz önünde bulundurulmalıdır.

\section{Kaynakça}

Aydın, E. (2021). Covid-19 döneminde EBA ile yapılan uzaktan eğitim sürecinde canlı Türkçe derslerinin değerlendirilmesi. Journal of History School, 50, 512-540.

Avcı, F., Akdeniz, E. C. (2021). Koronavirüs (Covid-19) salgını ve uzaktan eğitim sürecinde karşılaşılan sorunlar konusunda öğretmenlerin değerlendirmeleri. Uluslararası Sosyal Bilimler ve Eğitim Dergisi - USBED, 3/4, 117-154.

Başaran, M., Kılınçarslan, R. (2021). Uzaktan eğitimle ilkokuma yazma öğretiminde Web 2.0 araçlarıyla tasarlanan oyunların etkililiği. Türkiye Ĕ̆itim Dergisi, 6/1, 186-199.

Bayburtlu, Y.S. (2020). Covid-19 pandemi dönemi uzaktan eğitim sürecinde öğretmen görüşlerine göre Türkçe eğitimi. Turkish Studies, 15/4, 131-151.

Bölükbaş Kaya, F., Kahraman, F., Uysal, G. (2021). Yabancı dil olarak Türkçe öğretiminde kullanılan ders kitaplarının uzaktan öğretime uygunluğu: Yeni İstanbul örneği. Turkish Studies, 16/1, 63-84.

Büyüköztürk, Ş., Kılıç Çakmak, E., Akgün, Ö. E., Karadeniz, Ş., Demirel, F. (2019). Eğitimde bilimsel araştırma yöntemleri. Ankara: Pegem Akademi.

Doğan, S., Koçak, E. (2020). EBA sistemi bağlamında uzaktan eğitim faaliyetleri üzerine bir inceleme. Journal of Economics and Social Research - Ekonomi ve Sosyal Araşttrmalar Dergisi, 7/14, 110124.

Duman, G. B., Yurdakul, Y. (2021). Türkçenin yabancı dil olarak uzaktan öğretiminde öğreticilerin materyal kullanımı ve teknolojik alt yapıya yönelik tutum ve görüşleri. $Z f W T, 13 / 1,419-438$.

Fidan, M. (2020). Türkçe ders kitaplarındaki araştırma yönergelerinin niteliksel yönlerinin karşılaştırmalı analizi. Turkish Studies, 15/7, 2923-2941.

Geçgel, H., Kana, F., Eren, D. (2020). Türkçe eğitiminde dijital yetkinlik kavramının farklı değişkenler açısından incelenmesi. Ana Dili Eğitimi Dergisi, 8/3, 886-904.

Göçen Kabaran, G., Uşun, S. (2021). Dijital materyal tasarımı yeterlikleri ölçeği (dmtyö): bir ölçek geliştirme çalışması. Eğitim Teknolojisi Kuram ve Uygulama, 11/2, 281-307. DOI: 10.17943/etku.864296

Günaydın, Y. (2021). Türkçe öğretmenlerinin uzaktan eğitimde yazma becerisinin geliştirilmesine ilişkin yaşadıkları sorunlar ve çözüm önerileri. Atatürk Üniversitesi Türkiyat Araştırmaları Enstitüsü Dergisi, 71, 703- 724 .

Güngör, H., Çangal, Ö., Demir, T. (2020). Türkçenin yabancı dil olarak uzaktan öğretimine ilişkin öğrenici ve öğretici görüssleri. Gazi Üniversitesi Gazi Eğitim Fakültesi Dergisi, 4O/3, 1163-1191.

Gürdamar, T. N., Şehirli, A. Ş., Topçuoğlu Ünal, F. (2020). Uzaktan eğitim sürecinde kullanılan EBA'da yer alan Türkçe dersi okuma becerisi ile ilgili öğretmen görüşleri. International Journal of Language Academy, 8/4, 168-186.

İskender, M. E. (2021). Yabancı dil olarak Türkçe öğretiminde uzaktan eğitim derslerine ilişkin deneyimler. RumeliDE Dil ve Edebiyat Araşttrmaları Dergisi, (22), 96-117. DOI: $10.29000 /$ rumelide.885523.

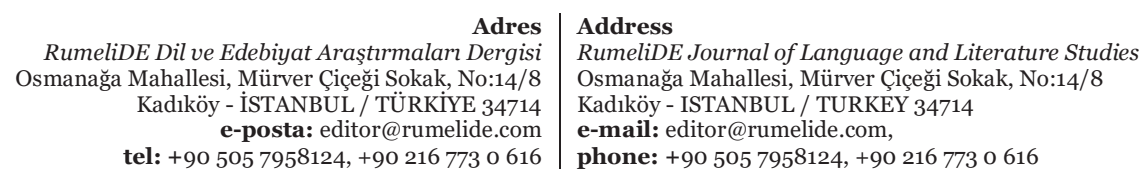


Kaplan, K., Gülden, B. (2021). Öğretmen görüşlerine göre salgın (COVID-19) dönemi uzaktan eğitim ortamında Türkçe eğitimi. RumeliDE Dil ve Edebiyat Araştırmaları Dergisi, (24), 233-258. DOI: 10.29000/rumelide.995291.

Karacaoğlu, M. Ö., Karakuş, N., Esendemir, N., Ucuzsatar, N. (2021). Uzaktan eğitim üzerine bir araştırma: "Türkçe öğretmenleriyle mülakatlar”. International Journal of Language Academy, 9/1, 124-144.

Karagöl, E. (2021). Uzaktan eğitim sürecinde ikinci/yabancı dil olarak Türkçe öğretimi ders kitaplarına yönelik öğretici görüşleri. Aydın TÖMER Dil Dergisi, 6/2, 121-159.

Karakuş, N., Esendemir, N., Ucuzsatar, N., Karacaoğlu, M. Ö. (2021). Türkçe dersleri özelinde uzaktan eğitim hakkında veli görüşleri. Ana Dili Ĕ̆itimi Dergisi, 9/3, 993-1011.

Kavan, N., Adıgüzel, A. (2021). Türkçe öğretmenlerinin salgın süreci eğitim faaliyetlerine ilişkin görüşlerinin incelenmesi. Elektronik Eğitim Bilimleri Dergisi, 10/19, 138-155.

Koç, E. S. (2021). İlkokul öğretim programlarının COVID-19 sonrası yaygınlaşan uzaktan eğitime uygunluğunun incelenmesi. International Anatolia Academic Online Journal Social Sciences Journal, 7/1, 24-36.

Kuloğlu, M. E. (2020). Uzaktan eğitim öğrencilerinin akademik başarıları, başarı motivasyonları ve can sıkıntıları arasındaki ilişkinin incelenmesi. Academic Platform Journal of Education and Change, 3/1, 48-60.

MEB (2019). Türkçe dersi öğretim programı. Ankara: MEB Yayınları.

Mete, G., Demir, T. (2021). Alan uzmanlarının Türkçe dersi dijital içerik geliştirme sürecine yönelik görüşleri. Akademik Sosyal Araştırmalar Dergisi, 9/116, 202-224.

Özer, Ö., Çekici, Y. E. (2020). Uzaktan eğitim yoluyla yürütülen Türk dili derslerinin değerlendirilmesi: nitel bir araştırma. RumeliDE Dil ve Edebiyat Araştırmaları Dergisi, (Ö7), 92- 110. DOI: 10.29000/rumelide.808251.

Özgül, E., Ceran, D., Yıldız, D. (2020). Uzaktan eğitimle yapılan Türkçe dersinin öğretmen görüşlerine göre değerlendirilmesi. Milli Ĕ̆itim Dergisi, 49/1, 395-412.

Pilancı, H., Saltık, O., Çalışır Zenci, S. (2020). Açık ve uzaktan yabancı dil olarak Türkçe öğreticileri için temel ilkeler. Uluslararası Beşerî Bilimler ve Ĕ̆itim Dergisi, 6/14, 516-529.

Sarıkaya, B. (2021). Açık öğretim ortaokulu Türkçe ders kitaplarındaki etkinliklerin değerlendirilmesi. Türkiye Eğitim Dergisi, 6/1, 244-261.

Şengül, K. (2021). Uzaktan eğitim sürecinde Türkçenin yabancı dil olarak öğretimi. RumeliDE Dil ve Edebiyat Araştırmaları Dergisi, (24), 174-222. DOI: 10.29000/rumelide.995482.

Yıldırım, A., Şimşek, H. (2008). Sosyal bilimlerde nitel araştırma yöntemleri. Ankara: Seçkin Yayıncılık.

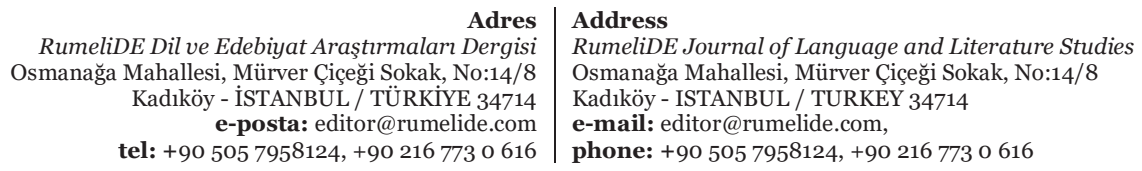

